\title{
A COMPARISON OF INFORMATION TECHNOLOGY MEDIATED CUSTOMER SERVICES BETWEEN THE U.S. AND CHINA
}

\author{
Suhong Li, Bryant University, sli@bryant.edu \\ Hal Records, Bryant University, hrecords@bryant.edu \\ Robert Behling, Arrowrock Industries, behlingr@hotmail.com
}

\begin{abstract}
Information technology mediated customer service is a reality of the $21^{\text {st }}$ century. More and more companies have moved their customer services from in store and in person to online through computer or mobile devices. Using 442 responses collected from one USA university (234 responses) and two Chinese universities (208 responses), the study investigates customer preferences over two service delivery models (either in store or online) on five types of purchasing (retail, eating-out, banking, travel and entertainment) and their perception difference in customer service quality between those two delivery models in the U.S. and China. The results show that the majority of the U.S. and Chinese students prefer in-store and in person for eating out and prefer computer/mobile devices for ordering tickets for travel and entertainment. In addition, more than half of the U.S. students prefer in person services for retail and banking, and this number reduces to $40 \%$ for Chinese students. In most customer service quality measurements, the results also show that Chinese students give higher ratings for ordering through a computer/mobile device than ordering in store, indicating ordering through computer/mobile devices has become more acceptable in China and has been perceived as having better customer services quality than in-store ordering.
\end{abstract}

Keywords: Customer Service Quality Metrics, Information Technology Mediated Customer Service, Information Technology Mediated Customer Service in China, On-line Shopping, Point of Sale Systems.

\section{INTRODUCTION}

Customer expectations with respect to services and user experience are evolving at such a fast pace that differentiating oneself from the competition is a challenge for almost every business in the modern marketplace (PwC, 2017). In 2017 the authors (Records, et al) reported on an exploratory study investigating service differentiation, defined as customer care and customer support. The original study found that organizations are faced with strategic management challenges with customer service operations, including how to effectively deploy digital technologies to improve efficiency and reduce costs associated with meeting customer service requirements. Pulach and Wunderlich (2016) found that technology-based service support has not received universal customer acceptance, with the trade-off being lower cost per service request for digital mediated requests vs. lower customer satisfaction with the digital service response. Kinderzerski (2018) is more optimistic, and reports that AI is revolutionizing customer service, predicting the right answer to a customer inquiry with a high level of confidence. While there is not agreement on the impact of deploying digital technologies to meet and satisfy service requests, additional study will provide a more coherent basis for decision making.

Creating great customer experiences is a primary goal for businesses in 2018. First contact resolution of a service request is a priority for $70 \%$ of the customers surveyed. (Golkar, 2018). The management challenge continues to be to provide high quality customer service while controlling costs. Replacing expensive human service support staff with digital systems is an approach many organizations are turning to. Customer service providers will experience their biggest shift into digital technology in 2018, in an effort to enable consumers to get quick, accurate and 
satisfactory service. Organizations are rapidly deploying digital technology to replace support staff, and digital interaction to handle service requests was more than $42 \%$ in 2017 (Kindzerski, 2018). It is predicted that by 2020 $85 \%$ of all service requests will be managed without human interaction (Golkar, 2018). The dilemma is that currently many customers prefer to deal with humans when requesting service and consider this interaction critical to meeting and satisfying their needs (Quering, et al, 2016). For example, recently one of the authors had some technical issues setting up a complex Panasonic telephone system and called Panasonic USA customer support for assistance. Calling the toll-free number rang down to an automated attendant which produced a list of options, none of which addressed the technical issues in question. After trying to find a means to meet the request and obtain a technical solution, and finding none, the automated system cheerfully said, "Good by" and hung up. This was not a pleasant experience, and points out the important challenges when replacing humans, and their ability to identify specific and unusual service requests, with digital systems that are still evolving effective artificial intelligence applications.

With pressure on profits, increasing salaries and benefits for customer service personnel, and increases in call volume as products and services become more complex, there is little question that economics will cause automated digital systems to be deployed in greater numbers, and they will play an increasing role in providing customer support and service. The authors study in 2017 (Records, et al) found there was some customer dissatisfaction with automated systems, and suggested organizations should pay more attention to providing quality customer service. Individuals surveyed were limited to respondents in the USA, and the results may or may not be applicable to a larger global population. This study expands the original by updating the survey questionnaire investigating customer service satisfaction with human interaction vs. digital technology interaction and includes respondents from both the USA and China.

Because of recent economic development, more than ever before, Chinese people enjoy middle class incomes and increased availability of goods and services. A recent survey found that customers in China were more satisfied with customer service experiences in 2017 than in previous years (Cemerka, 2017). Customer expectations may not always be similar in two distinct cultures, a recent study done by Accenture found that $75 \%$ of the Chinese consumers they surveyed reported increased service expectations over a year ago. This contrast with increased expectations for 30\% of the global population surveyed (Service Expectations, 2018). This differentiation was confirmed with a study by the cosmetics industry that found Chinese and European consumers engage very differently when engaged in ecommerce: Europeans employ the more traditional e-mail as their main service communication; Chinese consumers prefer using digital mobile technologies (Customer Expectations, 2017).

This research will focus on evaluating customer satisfaction with information technology mediated service. Survey responses from residents of the U.S. and China will be compared, looking for similarities and differences in the two surveyed groups.

\section{METHODOLOGY}

In order to evaluate customer preferences over service delivery models on the types of purchasing and their perception difference in customer service quality in the U.S. and China, we first identified five types of retail purchasing commonly done by potential survey respondents. These are: 1) retail; 2) eating out; 3) banking; 4) travel; and 5) entertainment. Next, we identified two dominant means or models by which purchasing can be done, either in store and in person, or through a computer or mobile device. For each type of purchasing, we developed seven items to measure how people perceive the relative value of each mode within each type of purchasing experience.

The survey was distributed in the U.S. through Qualtrics, largely to undergraduate students at a small private northeastern university with 234 valid respondents. The survey was then translated into Chinese and verified by two researchers that are fluent in Chinese. Next the survey was distributed through weChat to-undergraduate students at 
two large Chinese universities in Beijing with 208 valid respondents. For the US, $61 \%$ (142 respondents) are male and 39\% (92 respondents) are female. For Chinese students, $38 \%$ (78 respondents) are male and the rest (62\%, 130 respondents) are female. Coincidentally the aggregate gender mix is 50\% (220 respondents) are male and 50\% (222 respondents) are female.

Table 1 shows the types of hardware devices owned by respondents and their inclination toward technology adoption as described in technology adoption modeling (Davis, 1989). It is interesting to note the high and similar availability of owned hardware devices for both the U.S. and Chinese students. Nearly $100 \%$ have laptops and web-enabled smart phones, and about half of them have tablet computers, hence many have three personal electronic devices. About one third of the respondents consider themselves as early adopters of new technology and gadgets. Similar to our earlier U.S. findings (Records, Li, and Behling, 2017) it can be seen that the younger generation of Chinese and Americans have both incorporated technology into their daily life and have a more favorable attitude toward technology compared to older generations.

Given the age, hardware availability and pro-technology bias associated with the respondent population it was anticipated that survey results would be more friendly toward the use of IT mediated service than that of the purchasing population as a whole.

Table 1. Devices and Attitude toward Technology Adoption

\begin{tabular}{|l|l|l|}
\hline Devices I Own & $\begin{array}{l}\text { U.S. Respondents } \\
\text { Percent (Number) }\end{array}$ & $\begin{array}{l}\text { China Respondents } \\
\text { Percent (Number) }\end{array}$ \\
\hline Laptop/Computer & $100 \%(234)$ & $98.1 \% \%(204)$ \\
\hline Smart Phone & $98.3 \%(230)$ & $98.1 \%(204)$ \\
\hline Tablet (iPad, Samsung Note, etc.) & $47.9 \%(112)$ & $54.8 \%(114)$ \\
\hline E-Reader (Kinder Fire, Nook, etc.) & $15.4 \%(26)$ & $23.6 \%(49)$ \\
\hline Apple Watch & $6.8 \%(16)$ & $3.4 \%(7)$ \\
\hline $\begin{array}{l}\text { I am always among the first to adopt } \\
\text { new technology and gadgets }\end{array}$ & & \\
\hline Strongly Agree (Eagle Beaver) & $7.3 \%(17)$ & $9.1 \%(19)$ \\
\hline Agree (Early Adopter) & $29.1 \%(68)$ & $26.9 \%(56)$ \\
\hline $\begin{array}{l}\text { Neither Agree nor Disagree (Early } \\
\text { Majority) }\end{array}$ & $39.7 \%(93)$ & $51.4 \%(107)$ \\
\hline Disagree (Late Majority) & $20.9 \%(49)$ & $10.1 \%(21)$ \\
\hline $\begin{array}{l}\text { Strongly Disagree (Technically } \\
\text { Adverse) }\end{array}$ & $3.0 \%(7)$ & $2.4 \%(5)$ \\
\hline
\end{tabular}

\section{DATA ANALYSIS}

This section will discuss student purchasing preferences (in store or online) by five types of purchasing (Retail, EatingOut, Banking, Travel and Entertainment). Paired samples t-tested will be used to determine whether there exist significant differences between in-store and online purchasing for each metric of customer service quality in the U.S. and China respectively.

\section{Purchasing Preference by Type of Purchasing}

Table 2 shows a majority of U.S. and Chinese students prefer in store and in person for eating out. For ordering tickets for travel and entertainment, they prefer computer/mobile devices. For retail purchasing and banking, about $60 \%$ of American students prefer in person services, this number reduces to $40 \%$ for Chinese students. In sum, student preference for each type of purchasing is similar in both countries. It should be noted that a higher percentage of 


\section{Issues in Information Systems \\ Volume 19, Issue 1, pp. 1-10, 2018}

Chinese students prefer purchasing through computer/mobile devices than American students in each type of purchasing.

Table 3 further divides student preference for each type of purchasing by gender. In the U.S., a higher percentage of female students prefer in store and in person than males for retail and eating out. However, for banking, a lower percentage of females (52\%) prefer in store and in person than males (62\%). Similar patterns exist in China, more female students prefer in store and in person for retail and eating out and more male students prefer in store and in person for banking. Chi-square tests are used to see whether there is any gender difference in student preferences for each type of purchasing in each country. The results how that retail purchasing is significant at both country (for the U.S.: chi-square $=7.21, \mathrm{df}=1, \mathrm{p}=0.03$; for China: chi-square $=2.33, \mathrm{df}=1, \mathrm{p}=0.08$ ). There is no significant difference by gender in purchasing preferences for eating out, banking, travel and entertainment in either country. Female students in both countries prefer in-store and in person for retail purchasing.

Table 2. Student Preferences by Type of Purchasing

\begin{tabular}{|c|l|l|l|l|}
\hline \multirow{2}{*}{ Type of Purchasing } & \multicolumn{2}{|c|}{ Respondent Preferences (USA) } & \multicolumn{2}{c|}{ Respondent Preferences (China) } \\
\cline { 2 - 5 } & $\begin{array}{l}\text { In Store and in } \\
\text { Person }\end{array}$ & $\begin{array}{l}\text { Through } \\
\text { Computer/Mobile } \\
\text { Device }\end{array}$ & In Store and in Person & $\begin{array}{l}\text { Through } \\
\text { Computer/Mobile } \\
\text { Device }\end{array}$ \\
\hline Retail & $67.8 \%(156)$ & $32.2 \%(74)$ & $41.3 \%(86)$ & $58.7 \%(122)$ \\
\hline Eating Out & $90.8 \%(198)$ & $9.2 \%(20)$ & $84.6 \%(176)$ & $15.4 \%(32)$ \\
\hline Banking & $58.0 \%(112)$ & $42.0 \%(81)$ & $41.8 \%(87)$ & $58.2 \%(121)$ \\
\hline Travel & $17.7 \%(39)$ & $82.3 \%(181)$ & $3.8 \%(8)$ & $96.2 \%(200)$ \\
\hline Entertainment & $32.9 \%(71)$ & $67.1 \%(145)$ & $3.8 \%(8)$ & $96.2 \%(200)$ \\
\hline
\end{tabular}

Table 3. Student Preferences by Type of Purchasing by Gender

\begin{tabular}{|c|l|l|l|l|l|}
\hline \multirow{2}{*}{$\begin{array}{l}\text { Type of } \\
\text { Purchasing }\end{array}$} & & \multicolumn{2}{|c|}{ Respondent Preferences (USA) } & \multicolumn{1}{c|}{ Respondent Preferences (China) } \\
\cline { 2 - 6 } & & $\begin{array}{l}\text { In Store and in } \\
\text { Person }\end{array}$ & $\begin{array}{l}\text { Through } \\
\text { Computer/Mobile } \\
\text { Device }\end{array}$ & $\begin{array}{l}\text { In Store and in } \\
\text { Person }\end{array}$ & $\begin{array}{l}\text { Through } \\
\text { Computer/Mobile } \\
\text { Device }\end{array}$ \\
\hline \multirow{2}{*}{ Eating Out } & Male & $61.7 \%(87)$ & $38.3 \%(54)$ & $34.6 \%(27)$ & $65.4 \%(51)$ \\
\cline { 2 - 6 } & Female & $77.5 \%(69)$ & $22.5 \%(20)$ & $45.4 \%(59)$ & $54.6 \%(71)$ \\
\cline { 2 - 6 } & Male & $89.3 \%(117)$ & $10.7 \%(14)$ & $83.3 \%(65)$ & $16.7 \%(13)$ \\
\cline { 2 - 6 } Banking & Female & $93.1 \%(81)$ & $6.9 \%(6)$ & $85.4 \%(111)$ & $14.6 \%(19)$ \\
\cline { 2 - 6 } & Male & $61.9 \%(73)$ & $38.1 \%(45)$ & $44.9 \%(35)$ & $55.1 \%(43)$ \\
\hline \multirow{2}{*}{ Travel } & Female & $52.0 \%(39)$ & $48.0 \%(36)$ & $40.0 \%(52)$ & $60.0 \%(78)$ \\
\cline { 2 - 6 } & Male & $17.4 \%(23)$ & $82.6 \%(109)$ & $5.1 \%(4)$ & $94.9 \%(74)$ \\
\hline \multirow{2}{*}{ Entertainment } & Female & $18.2 \%(16)$ & $81.8 \%(72)$ & $3.1 \%(4)$ & $96.9 \%(126)$ \\
\cline { 2 - 6 } & Male & $33.1 \%(43)$ & $66.9 \%(87)$ & $5.1 \%(4)$ & $94.9 \%(74)$ \\
\cline { 2 - 6 } & Female & $32.6 \%(28)$ & $67.4 \%(58)$ & $3.1 \%(4)$ & $96.9 \%(126)$ \\
\hline
\end{tabular}

\section{Customer Services Quality Comparison}

For each of the five purchasing categories (Retail, Eating Out, Banking, Travel, and Entertainment), 7 items for measuring customer services quality (see table 4) were developed and students were asked to rate each service quality (on a scale of 1-5) based on where purchasing was conducted (in store and in person, or computer/mobile). Paired sample t-tests were then used to determine whether there is a significant perception difference in customer service quality between two modes of purchasing (in-store and in person, or computer/mobile device). The results show that there exists significant difference between in store and online purchasing for each category of purchasing in both the U.S. and China (See Tables 4-8). 


\section{Retail Purchasing}

Table 4 shows that for retail purchasing, there exist significant perception difference between in-store and online purchasing among the U.S. students for each metric of customer service quality. The result shows that in-store purchasing received higher means for 3 out of 7 service quality measures (you felt welcome to the store/ website/phone; you felt secure in doing your transactions; and customer service met your expectations). Previous analysis shows $68 \%$ of the U.S. students prefer in-store for retail purchasing. Those three measures (hospitality, security and customer service expectation) may be critical in determining students' preferences in in-store purchasing. Ordering through computer/mobile devices received higher means for the rest of the 4 items (you were able to locate what you wanted; checkout and payment was quick enough; total waiting time is reasonable and total time to complete transaction was reasonable), which are all related to speed and efficiency of ordering process. It can be concluded that the U.S. students consider in-store ordering has better security and customer service, which ordering through computer/mobile devices have better speed and efficiency.

For Chinese students, table 4 shows that for retail purchasing, there exist significant differences between in-store and online purchasing for each metric of customer service quality except the last item (customer service met your expectation). The results show that online purchasing received higher mean for all service quality measures except item 4 (you felt secure in doing your transaction) where in store and in person received higher mean.

The results show that compared to American students, more Chinese students consider retail purchasing through computer/mobile devices has better customer services quality than in-store purchasing.

Table 4. Retail Purchasing in USA and China

\begin{tabular}{|c|c|c|c|c|c|c|c|c|}
\hline & \multicolumn{4}{|c|}{ USA } & \multicolumn{4}{|c|}{ China } \\
\hline & \multicolumn{2}{|c|}{$\begin{array}{c}\text { Mean for Each } \\
\text { Mode of Purchasing }\end{array}$} & \multicolumn{2}{|c|}{$\begin{array}{c}\text { Paired Samples } \\
\text { t-test }\end{array}$} & \multicolumn{2}{|c|}{$\begin{array}{c}\text { Mean for Each } \\
\text { Mode of } \\
\text { Purchasing }\end{array}$} & \multicolumn{2}{|c|}{$\begin{array}{c}\text { Paired Samples } \\
\text { t-test }\end{array}$} \\
\hline & $\begin{array}{l}\text { In Store } \\
\text { and In } \\
\text { Person } \\
\end{array}$ & $\begin{array}{l}\text { Computer } \\
\text { /Mobile } \\
\text { Device } \\
\end{array}$ & $\begin{array}{l}\mathrm{t}- \\
\text { value }\end{array}$ & Significance & $\begin{array}{l}\text { In Store } \\
\text { and In } \\
\text { Person } \\
\end{array}$ & $\begin{array}{l}\text { Computer } \\
\text { /Mobile } \\
\text { Device } \\
\end{array}$ & $\begin{array}{l}\mathrm{t}- \\
\text { value }\end{array}$ & Significance \\
\hline $\begin{array}{l}\text { You felt } \\
\text { welcome to the } \\
\text { store/website }\end{array}$ & 3.97 & 3.77 & 3.54 & .000 & 3.56 & 3.81 & -4.68 & .000 \\
\hline $\begin{array}{l}\text { You were able to } \\
\text { locate what you } \\
\text { wanted }\end{array}$ & 3.86 & 4.20 & -5.20 & .000 & 3.48 & 3.88 & -5.35 & .000 \\
\hline $\begin{array}{l}\text { Checkout and } \\
\text { payment was } \\
\text { quick enough }\end{array}$ & 3.66 & 4.24 & -6.96 & .000 & 3.54 & 4.11 & -8.64 & .000 \\
\hline $\begin{array}{l}\text { You felt secure } \\
\text { in doing your } \\
\text { transactions }\end{array}$ & 4.25 & 3.75 & 7.30 & .000 & 3.91 & 3.59 & 5.47 & .000 \\
\hline $\begin{array}{l}\text { Total waiting } \\
\text { time is } \\
\text { reasonable }\end{array}$ & 3.65 & 4.23 & -8.85 & .000 & 3.30 & 3.92 & -8.66 & .000 \\
\hline $\begin{array}{l}\text { Total time to } \\
\text { complete } \\
\text { transaction was } \\
\text { reasonable }\end{array}$ & 3.89 & 4.17 & -4.45 & .000 & 3.42 & 3.67 & -3.17 & .002 \\
\hline $\begin{array}{l}\text { Customer } \\
\text { Service met your } \\
\text { expectations }\end{array}$ & 3.89 & 3.68 & 3.29 & .001 & 3.43 & 3.52 & -1.41 & .161 \\
\hline
\end{tabular}




\section{Eating-Out}

For the U.S. students, Table 5 shows there exist significant differences between in store and online for 4 out of 7 items (you felt welcome to the restaurant/website; you were able to locate what you wanted; you felt secure in doing your transactions; and customer service met your expectations). Order in store and in person received higher mean in all 4 items than ordering by computer/mobile service. This finding is consistent with previous the section showing that US students chose in store and in person as their preferred method of ordering eating out.

For Chinese students, table 5 shows that for eating out, there exist significant differences between in store and online for 4 out of 7 items. In store purchasing received a significantly higher mean for the three items (you felt welcome to the restaurant/website; you felt secure in doing your transactions; and customer service met your expectations). In contrast, ordering eating-out through computer/mobile devices received a higher mean for the item (checkout and payment was quick enough). Again, this finding is consistent with the previous section since Chinese students also chose in store and in person as their most preferred method of ordering eating out.

American and Chinese students both prefer in-store and in person for eating out. They consider in-store ordering as more welcoming, more secure, and better meeting their customer service expectations. The result also shows that US students tend to give q higher rating for each customer service quality measurement than do Chinese students.

\section{$\underline{\text { Banking }}$}

Table 6 shows that for American students, all service quality measures are significant except one (total time to complete transaction was reasonable). In store banking received a higher mean for 4 measures (you felt welcome to the bank/website; you could complete those transactions you wished to do; you felt secure in doing your transactions; and customer service met your expectations). Online banking received a higher mean for one measurement (total waiting time is reasonable). This is in consistent with previous results showing that more than half (58\%) of the U.S. students prefer in-store banking than online.

For Chinese students, table 6 shows that for banking, 3 service quality measures are significant. Among those three items, in-store banking received a higher mean for one item (you felt secure in doing your transactions), and online banking received a higher mean for two items (total waiting time is reasonable; total time to complete transaction was reasonable). Previous results show that $58 \%$ of the Chinese students prefer on-line banking. It seems that transaction time is more important than security in choosing preferred method for banking for Chinese students.

Table 6 shows that in-store banking in China receives the lowest mean for most of the items, and in-store banking in the U.S. received the highest mean for most of the items. In addition, total waiting time in bank in China received the lowest mean among all the items. It is interesting to see that the U.S. students consider in-store banking has better customer service quality, while Chinese students consider online banking has better customer service quality.

\section{Travel}

Table 7 show that for travel, there exist significant differences between in store and online for most customer service quality measures for both American and Chinese students. Purchasing through computer/mobile devices receive higher means for all service quality measures except one item (you felt secure in doing your transactions). Those are consistent with our earlier findings, showing students chose computer/mobile device as their most preferred way of purchasing travel tickets.

In addition, American students consider in-store purchasing is more secure than online. However, for Chinese students, there is no significant difference regarding the security question between in store and online purchasing. This is surprising considering ordering in store is perceived more secure compare to ordering through computer/mobile device for retail, eating-out and banking in earlier analysis for Chinese students. 


\section{Issues in Information Systems}

Volume 19, Issue 1, pp. 1-10, 2018

The result shows that Chinese students have lower means for purchasing travel tickets in-store for all service quality measures than American students. Both American and Chinese students have similar ratings for purchasing travel tickets through computer/mobile devices.

Table 5. Eating-Out in USA and China

\begin{tabular}{|c|c|c|c|c|c|c|c|c|}
\hline & \multicolumn{4}{|c|}{ USA } & \multicolumn{4}{|c|}{ China } \\
\hline & \multicolumn{2}{|c|}{$\begin{array}{c}\text { Mean for Each Mode } \\
\text { of Ordering Eating } \\
\text { Out }\end{array}$} & \multicolumn{2}{|c|}{$\begin{array}{c}\text { Paired Samples t- } \\
\text { test }\end{array}$} & \multicolumn{2}{|c|}{$\begin{array}{c}\text { Mean for Each Mode } \\
\text { of Ordering Eating } \\
\text { Out }\end{array}$} & \multicolumn{2}{|c|}{$\begin{array}{c}\text { Paired Samples t- } \\
\text { test }\end{array}$} \\
\hline & $\begin{array}{l}\text { In } \\
\text { Store }\end{array}$ & $\begin{array}{l}\text { Computer } \\
\text { /Mobile } \\
\text { Device }\end{array}$ & $\begin{array}{l}\mathrm{t}- \\
\text { value }\end{array}$ & Significance & $\begin{array}{l}\text { In } \\
\text { Store }\end{array}$ & $\begin{array}{l}\text { Computer } \\
\text { /Mobile } \\
\text { Device } \\
\end{array}$ & $\begin{array}{l}\mathrm{t}- \\
\text { value }\end{array}$ & Significance \\
\hline $\begin{array}{l}\text { You felt welcome to the } \\
\text { restaurant/website }\end{array}$ & 4.07 & 3.45 & 7.96 & .000 & 3.67 & 3.53 & 2.25 & .026 \\
\hline $\begin{array}{l}\text { You could find what } \\
\text { you wanted on menu }\end{array}$ & 4.32 & 3.79 & 7.74 & .000 & 3.71 & 3.65 & 0.98 & .327 \\
\hline $\begin{array}{l}\text { Checkout and payment } \\
\text { was quick enough }\end{array}$ & 3.96 & 3.96 & 0.00 & 1.000 & 3.73 & 4.05 & -6.12 & .000 \\
\hline $\begin{array}{l}\text { You felt secure in doing } \\
\text { your transactions }\end{array}$ & 4.25 & 3.75 & 6.44 & .000 & 3.90 & 3.64 & 4.66 & .000 \\
\hline $\begin{array}{l}\text { Total waiting time is } \\
\text { reasonable }\end{array}$ & 3.87 & 3.83 & 0.58 & .562 & 3.25 & 3.28 & -0.38 & .704 \\
\hline $\begin{array}{l}\text { Total time to complete } \\
\text { transaction was } \\
\text { reasonable }\end{array}$ & 4.00 & 3.92 & 1.36 & .174 & 3.60 & 3.47 & 1.92 & .057 \\
\hline $\begin{array}{l}\text { Customer Service met } \\
\text { your expectations }\end{array}$ & 4.05 & 3.68 & 5.42 & .000 & 3.63 & 3.38 & 3.87 & .000 \\
\hline
\end{tabular}

Table 6. Banking in USA and China

\begin{tabular}{|c|c|c|c|c|c|c|c|c|}
\hline & \multicolumn{4}{|c|}{ USA } & \multicolumn{4}{|c|}{ China } \\
\hline & \multicolumn{2}{|c|}{$\begin{array}{c}\text { Mean for Each Mode } \\
\text { of Banking }\end{array}$} & \multicolumn{2}{|c|}{$\begin{array}{c}\text { Paired Samples t- } \\
\text { test }\end{array}$} & \multicolumn{2}{|c|}{$\begin{array}{c}\text { Mean for Each Mode } \\
\text { of Banking }\end{array}$} & \multicolumn{2}{|c|}{$\begin{array}{c}\text { Paired Samples t- } \\
\text { test }\end{array}$} \\
\hline & $\begin{array}{l}\text { In } \\
\text { Store }\end{array}$ & $\begin{array}{l}\text { Computer } \\
\text { /Mobile } \\
\text { Device }\end{array}$ & $\begin{array}{l}\mathrm{t}- \\
\text { value }\end{array}$ & Significance & $\begin{array}{l}\text { In } \\
\text { Store }\end{array}$ & $\begin{array}{l}\text { Computer } \\
\text { /Mobile } \\
\text { Device }\end{array}$ & $\begin{array}{l}\mathrm{t}- \\
\text { value }\end{array}$ & Significance \\
\hline $\begin{array}{l}\text { You felt welcome to the } \\
\text { bank/website }\end{array}$ & 4.29 & 4.07 & 3.56 & .000 & 3.53 & 3.66 & -1.89 & .060 \\
\hline $\begin{array}{l}\text { You could complete } \\
\text { those transactions you } \\
\text { wished to do }\end{array}$ & 4.45 & 4.11 & 5.51 & .000 & 3.73 & 3.69 & 0.61 & .545 \\
\hline $\begin{array}{l}\text { You felt secure in doing } \\
\text { your transactions }\end{array}$ & 4.51 & 3.89 & 8.12 & .000 & 4.04 & 3.61 & 7.59 & .000 \\
\hline $\begin{array}{l}\text { Total waiting time is } \\
\text { reasonable }\end{array}$ & 4.00 & 4.26 & -3.96 & .000 & 2.67 & 3.89 & $\begin{array}{r}- \\
14.74\end{array}$ & .000 \\
\hline $\begin{array}{l}\text { Total time to complete } \\
\text { transaction was } \\
\text { reasonable }\end{array}$ & 4.11 & 4.21 & -1.52 & .129 & 2.99 & 3.83 & 10.19 & .000 \\
\hline $\begin{array}{l}\text { Customer Service met } \\
\text { your expectations }\end{array}$ & 4.38 & 4.03 & 5.17 & .000 & 3.50 & 3.58 & -1.17 & .242 \\
\hline
\end{tabular}


Table 7. Travel in USA and China

\begin{tabular}{|c|c|c|c|c|c|c|c|c|}
\hline & \multicolumn{4}{|c|}{ USA } & \multicolumn{4}{|c|}{ China } \\
\hline & \multicolumn{2}{|c|}{$\begin{array}{c}\text { Mean for Each } \\
\text { Mode of Ticket } \\
\text { Purchasing }\end{array}$} & \multicolumn{2}{|c|}{$\begin{array}{c}\text { Paired Samples } \\
\text { t-test }\end{array}$} & \multicolumn{2}{|c|}{$\begin{array}{l}\text { Mean for Each } \\
\text { Mode of Ticket } \\
\text { Purchasing }\end{array}$} & \multicolumn{2}{|c|}{$\begin{array}{c}\text { Paired Samples } \\
\text { t-test }\end{array}$} \\
\hline & $\begin{array}{l}\text { In Store } \\
\text { and In } \\
\text { Person }\end{array}$ & $\begin{array}{l}\text { Computer } \\
\text { /Mobile } \\
\text { Device }\end{array}$ & $\begin{array}{l}\mathrm{t}- \\
\text { value }\end{array}$ & Significance & $\begin{array}{l}\text { In Store } \\
\text { and In } \\
\text { Person }\end{array}$ & $\begin{array}{l}\text { Computer } \\
\text { /Mobile } \\
\text { Device }\end{array}$ & $\begin{array}{l}\mathrm{t}- \\
\text { value }\end{array}$ & Significance \\
\hline $\begin{array}{l}\text { You felt } \\
\text { welcome at the } \\
\text { counter or at the } \\
\text { website }\end{array}$ & 3.91 & 3.98 & -.90 & .369 & 3.12 & 3.85 & 10.44 & .000 \\
\hline $\begin{array}{l}\text { You could } \\
\text { complete those } \\
\text { transactions you } \\
\text { wished to do }\end{array}$ & 4.05 & 4.17 & -1.93 & .055 & 3.51 & 4.09 & -9.52 & .000 \\
\hline $\begin{array}{l}\text { Checkout and } \\
\text { payment was } \\
\text { quick enough }\end{array}$ & 3.76 & 4.15 & -5.78 & .000 & 3.26 & 4.16 & 12.44 & .000 \\
\hline $\begin{array}{l}\text { You felt secure } \\
\text { in doing your } \\
\text { transactions }\end{array}$ & 4.12 & 3.97 & 2.40 & .017 & 3.75 & 3.83 & -1.36 & .175 \\
\hline $\begin{array}{l}\text { Total waiting } \\
\text { time is } \\
\text { reasonable }\end{array}$ & 3.55 & 4.2 & -8.81 & .000 & 2.75 & 4.08 & $\begin{array}{c}- \\
15.69\end{array}$ & .000 \\
\hline $\begin{array}{l}\text { Total time to } \\
\text { complete } \\
\text { transaction was } \\
\text { reasonable }\end{array}$ & 3.74 & 4.17 & -6.10 & .000 & 2.88 & 4.09 & $\begin{array}{c}- \\
14.69\end{array}$ & .000 \\
\hline $\begin{array}{l}\text { Customer } \\
\text { Service met your } \\
\text { expectations }\end{array}$ & 3.93 & 4.00 & -1.00 & .320 & 3.31 & 4.00 & -9.92 & .000 \\
\hline
\end{tabular}

\section{$\underline{\text { Entertainment }}$}

Table 8 shows that for American students, there exist significant perception difference between in-store and online purchasing for 3 out of 7 measures. Purchasing entertainment tickets through computer/mobile device received higher means for those three items (checkout and payment was quick enough; total waiting time is reasonable; total time to complete transaction was reasonable). American students consider online ticket purchasing having shorter waiting time and faster transactions compared to in-store purchasing.

For Chinese students, table 8 shows there exists significant differences for all service quality measures between in store and online. Online purchasing has a higher mean for all measurement including the item (you felt secure in doing your transaction). This is unexpected as online is usually viewed as less secure than in store. 
Issues in Information Systems

Volume 19, Issue 1, pp. 1-10, 2018

Table 8. Entertainment in USA and China

\begin{tabular}{|c|c|c|c|c|c|c|c|c|}
\hline & \multicolumn{4}{|c|}{ USA } & \multicolumn{4}{|c|}{ China } \\
\hline & \multicolumn{2}{|c|}{$\begin{array}{l}\text { Mean for Each } \\
\text { Mode of Ticket } \\
\text { Purchasing }\end{array}$} & \multicolumn{2}{|c|}{$\begin{array}{c}\text { Paired Samples t- } \\
\text { test }\end{array}$} & \multicolumn{2}{|c|}{$\begin{array}{l}\text { Mean for Each } \\
\text { Mode of Ticket } \\
\text { Purchasing }\end{array}$} & \multicolumn{2}{|c|}{$\begin{array}{c}\text { Paired Samples t- } \\
\text { test }\end{array}$} \\
\hline & $\begin{array}{l}\text { In Store } \\
\text { and In } \\
\text { Person }\end{array}$ & \begin{tabular}{|l} 
Computer \\
/Mobile \\
Device
\end{tabular} & $\begin{array}{l}\mathrm{t}- \\
\text { value }\end{array}$ & Significance & $\begin{array}{l}\text { In Store } \\
\text { and In } \\
\text { Person }\end{array}$ & $\begin{array}{l}\text { Computer } \\
\text { /Mobile } \\
\text { Device }\end{array}$ & $\begin{array}{l}\mathrm{t}- \\
\text { value }\end{array}$ & Significance \\
\hline $\begin{array}{l}\text { You felt } \\
\text { welcome at the } \\
\text { counter or at the } \\
\text { website }\end{array}$ & 4.14 & 4.16 & -.26 & .792 & 3.35 & 3.90 & -8.16 & .000 \\
\hline $\begin{array}{l}\text { You could } \\
\text { complete those } \\
\text { transactions you } \\
\text { wished to do }\end{array}$ & 4.23 & 4.32 & -1.64 & .102 & 3.56 & 4.10 & -9.07 & .000 \\
\hline $\begin{array}{l}\text { Checkout and } \\
\text { payment was } \\
\text { quick enough }\end{array}$ & 3.97 & 4.31 & -4.68 & .000 & 3.45 & 4.18 & $\begin{array}{c}- \\
11.60\end{array}$ & .000 \\
\hline $\begin{array}{l}\text { You felt secure } \\
\text { in doing your } \\
\text { transactions }\end{array}$ & 4.26 & 4.19 & 1.17 & .245 & 3.68 & 3.88 & -2.92 & .004 \\
\hline $\begin{array}{l}\text { Total waiting } \\
\text { time is } \\
\text { reasonable }\end{array}$ & 3.85 & 4.33 & -6.26 & .000 & 2.86 & 4.12 & ${ }^{-}-\overline{6.58}$ & .000 \\
\hline $\begin{array}{l}\text { Total time to } \\
\text { complete } \\
\text { transaction was } \\
\text { reasonable }\end{array}$ & 3.95 & 4.28 & -4.40 & .000 & 3.06 & 4.11 & $\begin{array}{c}- \\
13.81\end{array}$ & .000 \\
\hline $\begin{array}{l}\text { Customer } \\
\text { Service met your } \\
\text { expectations }\end{array}$ & 4.09 & 4.17 & -1.10 & .271 & 3.38 & 3.98 & -9.30 & .000 \\
\hline
\end{tabular}

\section{CONCLUSIONS}

This study investigates customer preferences over two service delivery models (either in store or online), on five types of purchasing (retail, eating-out, banking, travel and entertainment) and their perception difference in customer service quality between those two delivery models in the U.S. and China. Results show that the majority of U.S. and Chinese students prefer in-store and in person for eating out and prefer computer/mobile device for ordering tickets for travel and entertainment. In addition, more than half of the U.S. students prefer in person services for retail and banking, and this number reduces to $40 \%$ for Chinese students. The results also show that Chinese students give higher ratings for ordering through computer/mobile devices in most of customer service quality measurements than in ordering in store on all types of purchasing, indicating ordering through computer/mobile devices has become more acceptable in China and is perceived as having better customer service quality than in-store purchasing.

In general, U.S. students consider traditional in-store and in-person purchasing has better hospitality and security, and meets their customer service expectations better, while ordering through computer/mobile devices has shorter waiting and transaction times. Chinese students tend to favor ordering through computer/mobile devices in all types of purchasing except eating out. They consider online ordering to have overall better customer service quality. 
It is interesting to note that there are far more similarities than differences between perceptions of information mediated customer services in the U.S. and in China. It is also interesting to note that by far the single worst customer service experiences in both countries are in store and in person total waiting time, and total time to complete transactions. This phenomenon is likely driving customers away from the in-store experience and toward on line purchasing. It suggests that traditional stores need to review and streamline their checkout procedures and practices if they wish to stem the flow of business from brick and mortar to online stores. Is it any wonder that Amazon, Walmart online, Kohls online, and other online retailers are capturing more of the purchasing transactions?

\section{Future Research}

As described in our previous work, areas of future research for information technology mediated customer service should include development of a model that links current customer adaptation realities to profit motivated changes in customer service, and another that measures customer willingness to integrate on-line ordering with showroom viewing. Future research can also extend the same study to other countries where technology is not advanced as USA or China.

\section{REFERENCES}

Cemerka, L. (2017). China's Changing Customer Service Expectations, Retrieved from: www.teleperformance.com/eu-us/china-is-changing-expectations/

Customer Expectations. (2017). How Chinese and European Customer Expectations Differ, Retrieved from: www.cosmetricsbusiness.com/article_page/how-chinese-and-european-consumer-expectations-differ.

Davis, F., (1989). Perceived usefulness, perceived ease of use, and user acceptance of information technology, MIS Quarterly, 13(3), 319-340.

Golkar, G. (2018). Top 7 Customer Engagement Trends in 2018, Digital Customer Engagement, Retrieved from: www.vocal/com.com/blog/digital-customer-engagement/top-7-customer-engagement-trends-in-2018.

Kindzerski, L. (2018). The Top 10 Customer Experience Trends in 2018, PRNewswire, Retrieved from: www.prnewswire.com/news-release/the-top-10-customer-experience-trends-in-2018.

Polach, S., \& Wunderlich, N. (2016). Contrasting Risk Perceptions of Technology-based Service Innovations in inter-organizational Settings, Journal of Business Research, 69(7), 2424-2431.

PwC Report. (2017). Understanding Digital Expectations, Retrieved from: www.thedigitalinsurer.com/understanding-digital-expectations-pwc-report/

Quiring, K., DeAngelis, F. \& Gasull, E. (2016). Digital Disconnection in Customer Engagements. Retrieved from: www.accenture.com/us-en/insight-digital-disconect.

Records, H., Li, S. \& Behling, R. (2017). Information Technology, Service Quality and Consumer Satisfaction, Issues in Information Systems, 18(1), 1-10.

Service Expectations. (2018) Chinese Customer Service Expectations, Retrieved from: www.customerservicemanager.com/chinese-service-coustomer-expectations. 